\title{
Mapping the Cultural Heritage of Dissent. New Sources, New Knowledge and New Narrative(s) on European Identity ${ }^{1^{*}}$
}

\author{
Cristina Petrescu ${ }^{2}$
}

Recibido: 15 de junio de 2020 / Aceptado: 15 de julio 2020

\begin{abstract}
The COURAGE project has created an open-access e-database that collected new sources, summarized new knowledge and created new narratives about a hitherto divided European cultural heritage: the legacy of dissent under the communist dictatorships in East-Central Europe. The Romanian COURAGE team has highlighted a new sense of being European, which was experienced by many ordinary individuals who created everyday meanings and cultural practices as if they lived in a free country. This identification with Europe is reflected in previously unknown private collections created by those who envisaged strategies of opposing the communist dictatorships that had rejected the fundamental values underpinning the European Union: rule-of-law, human rights, civil liberties, etc. The opposite values are reflected in the collections created by the Romanian communist secret police, the Securitate, which remind of a non-democratic European past and warn against the danger of forgetting it under the pressure of the current challenges the European project is facing.

Keywords: European identity; East-Central Europe; communist dictatorship; cultural heritage; memory; dissent; secret police; civil courage
\end{abstract}

\section{[es] La cartografía de la herencia cultural del disenso. Nuevas fuentes, nuevo conocimiento y nueva(s) narrativa(s) de la identidad europea}

Resumen. El proyecto COURAGE ha creado una base de datos electrónica de acceso abierto que recopiló nuevas fuentes, resumió nuevos conocimientos y creó nuevas narrativas sobre un patrimonio cultural europeo hasta ahora dividido: el legado de la disidencia bajo las dictaduras comunistas en Europa Central y Oriental. El equipo rumano de COURAGE ha resaltado un nuevo sentido de ser europeo, que fue experimentado por muchas personas comunes que crearon significados cotidianos y prácticas culturales como si vivieran en un país libre. Esta identificación con Europa se refleja en colecciones privadas previamente desconocidas creadas por aquellos que preveían estrategias de oposición a las dictaduras comunistas que habían rechazado los valores fundamentales que sustentan la Unión Europea: estado de derecho, derechos humanos, libertades civiles, etc. Los valores opuestos se reflejan en las colecciones creadas por la policía secreta comunista rumana, la Securitate, que recuerdan un pasado europeo no democrático y advierten sobre el peligro de olvidarlo bajo la presión de los desafíos actuales que enfrenta el proyecto europeo.

Palabras clave: Identidad europea; Europa central y oriental; dictadura comunista; patrimonio cultural; memoria; disensión; policía secreta; coraje civil

Sumario. Questions of definitions and method. Searching for collections. Instead of conclusions.

\footnotetext{
${ }_{1}^{1} \quad *$ This study has been developed in the frame of the project COURAGE - Cultural Opposition: Understanding the Cultural Heritage of Dissent in the Former Socialist Countries. This project has received funding from the European Union's Horizon 2020 research and innovation programme under Grant Agreement No 692919.

2 Faculty of Political Science, University of Bucharest (FSPUB)

E-mail: cristina.petrescu@fspub.unibuc.ro
} 
Cómo citar: Petrescu, C. (2020). Mapping the Cultural Heritage of Dissent. New Sources, New Knowledge and New Narrative(s) on European Identity. Cuadernos de Historia Contemporánea, Vol. 42: 79-96.

There is little consensus on the meaning of European identity, thus often spelled identity/identities, but there is large consensus that the survival of the European Union as political, economic and cultural transnational project is heavily dependent on the successful building of a widely assumed collective identity. ${ }^{3}$ Grand European historical narratives underpinning European identity by covering the past from Pericles to Putin include little input coming from East-Central Europe, because pathbreaking processes rarely originate there. If the common past is limited to the recent "age of the extremes" "with its series of devastating conflicts and routine use of violence, then East-Central Europe receives matching prominence in the historical representations focusing on the making of Europe. ${ }^{5}$ Although memory is still dividing along the Iron Curtain, new histories try to bridge the gap and emphasize the similar experiences in facing twentieth-century dictatorships all across the continent. ${ }^{6}$ Increasingly, East-Central Europe has become part of the common European narrative about the victory of democracy in the clash with the fascist and then communist regimes. ${ }^{7}$ Yet, the making of the European identity remains un "unfinished business," as it requires a multifaceted approach. ${ }^{8}$ In an attempt to support research on this issue, the European Union financed among many others a research project meant to highlight the legacy of those who courageously defied before 1989 the communist dictatorships in East-Central Europe and thus contributed to the subsequent enlargement of Europe, as the above-mentioned narrative goes. Emblematically, the project took the acronym COURAGE. ${ }^{9}$

This study covers the research on Romania carried in the frame of this project, but takes advantage of the intrinsic comparative dimension of the project, and deliberately highlights as result a hitherto ignored process of identification with Europe under the adverse conditions of living behind the Iron Curtain. Fascinated by pop culture in Western countries, interested in state-of-the art developments in their field, or simply copying latest fashions, a large variety of individuals in East-Central Europe imagined themselves as part of the wider, transnational European community without entertaining hopes to change the political regime. This silent process con-

3 Shore, Chris: Building Europe: The Cultural Policies of European Integration, New York, Routledge, 2000; Sierp, Aline. History, Memory, and Trans-European Identity: Unifying Divisions, New York, Routledge, 2014.

4 Hobsbawm, Eric: The Age of the Extremes: The Short Twentieth Century, 1914-1991, London, Abacus, 1995.

5 Mork, Andreea and Perikles Christodoulou (Eds.): Creating the House of European History, Brussels, European Union, 2018.

6 Faraldo, José M.: Europa clandestina: Resistencia a las ocupaciones nazi y soviética. 1938-1948, Madrid, Alianza Editorial, 2011.

7 Blaive, Muriel; Christian Gerbel and Thomas Lindenberger, (Eds.): Clashes in European Memory. The Case of Communist Repression and the Holocaust, Innsbruck, Studienverlag, 2011; Snyder, Timothy: Bloodlands: Europe between Hitler and Stalin, London, Vintage, 2011; Blacker, Uilleam; Alexander Etkind and Julie Fedor, (Eds.): Memory and Theory in Eastern Europe, New York, Palgrave Macmillan, 2013.

8 European Commission, Directorate-General for Research and Innovation, Socio-Economic Sciences and Humanities, The Development of European Identity/Identities: Unfinished Business - A Policy Review Brussels, European Commission, 2012.

9 European Commission, Directorate-General for Research and Innovation, Open and Inclusive Societies, Cultural Heritage and European Identities - List of projects, 2014-2017, Brussels, European Commission, 2018, pp. 53-55. 
tributed from before 1989 to the bottom-up emergence of European identity in Soviet-dominated countries, which was far more substantial than the simple dreaming of having the same standard of living as in the more affluent countries of the West, this author argues. Simply put, this study illustrates that beyond the political, economic and social history dividing postwar Europe along the Iron Curtain, there is cultural and intellectual history converging the two halves and offing a solid bases for building upon a common European identity. ${ }^{10}$

\section{Questions of definitions and method}

Methodologically, the project aimed at discovering, inventorying and creating an electronic database of so-called "collections of cultural opposition" in all the former communist countries in Europe, while emphasizing the origins, uses and changing roles of these collections in their social, political and cultural contexts. ${ }^{11}$ In short, the project searched for new sources - the hitherto unexplored and often unknown collections - and attempted at producing new knowledge - the cultural opposition as reflected in these collections. It was the call for projects that launched this new concept of cultural opposition, never used before by students of the communist regimes or by practitioners of what this concept could refer to. Thus, in order to identify the collections, one had to first formulate a working definition for the suggested concept of cultural opposition. Any new definition had to relate to those already endorsed by current use and in this case the most widely employed term is dissent. ${ }^{12}$ As studied in the existing literature, dissent was an open act of defying the official ideology, a public criticism against dictatorships that did not offer other means of sanctioning the abuses of power, and thus it was explicitly or implicitly political, even when avoided politics. As coined, cultural opposition enlarged, on the one hand, the range of oppositional acts from purely political to cultural ${ }^{13}$, while restricting, on the other hand, the community of individuals involved in such acts, for it referred to oppo-

10 Mitter, Rana and Patrick Major, (Eds.): Across the Blocs: Cold War Cultural and Social History, London, Frank Cass, 2004.

11 The database, named registry, is to be found at http://cultural-opposition.eu/registry/

12 Medvedev, Roy A.: On Soviet Dissent, London, Constable, 1980; Curry, Jane Leftwich (Ed.): Dissent in Eastern Europe, New York, Praeger, 1983; Havel, Václav: Living in Truth, London, Faber and Faber, 1986; Kennedy, Michael D.: Professionals, Power and Solidarity in Poland: A Critical Sociology of Soviet-Type Society, Cambridge, Cambridge University Press, 1991; Joppke, Christian: East German Dissidents and the Revolution of 1989: Social Movement in a Leninist Regime, New York, New York University Press, 1995; Falk, Barbara: The Dilemmas of Dissidence in East-Central Europe: Citizen Intellectuals and Philosopher Kings, Budapest, Central European University Press, 2003; Pollack, Detlef, and Jan Wielgohs, (Eds.): Dissent and Opposition in Communist Eastern Europe: Origins of Civil Society and Democratic Transition, Aldershot, UK, Ashgate, 2004.

13 Skilling, Gordon: Samizdat and an Independent Society in Central and Eastern Europe, Columbus. OH, Ohio State University Press, 1989; Hamersky, Heidrun: Samizdat: Alternative Culture in Central and Eastern Europe from the 1960s to the 1980s, Bremen, Research Centre for East European Studies at the University of Bremen, 2002; Bolton, Jonathan: Worlds of Dissent: Charter 77, The Plastic People of the Universe, and Czech Culture under Communism, Cambridge, MA, Harvard University Press, 2012; Komaromi, Ann: Uncensored: Samizdat Novels and the Quest for Autonomy in Soviet Dissidence, Evanston, IL, Northwestern University Press, 2015; Bazin, Jérôme; Pascal Dubourg Glatigny and Piotr Piotrowski, (Eds.), Art beyond Borders: Artistic Exchange in Communist Europe, 1945-1989, Budapest, Central European University Press, 2016. 
sition, therefore networks, and excluded the isolated dissidents. ${ }^{14}$ Thus, this author focused on the practice of dissent and searched for cultural opposition taking into account evidence of thought and action illustrating a discernible variation from the imposed system of meanings, including those obliquely manifested and carefully avoiding an open conflict. This working definition of cultural opposition offered, this study illustrates, a basis for fresh inquiries on the mental horizon of the silent mass of citizens who quietly embraced other ideas and values than those imposed on them by the party state without having any militant or revolutionary goals. So far, such individuals have been subject of research on everyday life routines, not on cultural heritage.

Given the poverty of dissent in communist Romania ${ }^{15}$, a successful research demanded the enlargement of the existing canon. ${ }^{16}$ As these covertly conflicting thoughts and actions aimed at rather preserving than endangering their endeavours, the above definition covers far more numerous and diverse cases, offering a more comprehensive range of experiences. However, the canon could be further enlarged by going beyond high culture and adopting a definition of culture as referring to patterns of thinking, shared understandings and behavioural practices regarding almost every aspect of everyday life rather than high culture solely. ${ }^{17}$ Moreover, the very idea of opposition to the former regime can be seen beyond a dichotomic and static view, for this type of experience was neither uniform nor perpetual. ${ }^{18}$ Individuals living under a dictatorship crossed borders more often than not from repressed to tolerated and even to supported, while those supported could fall into disgrace at any time. In short, on the basis of a practice of dissent including covert yet identifiable manifestations, an anthropological definition of culture, and a dynamic stance of opposition to the communist regime, the existing Romanian canon of anti-communism is substantially enlarged and the object of research expanded so much as to include almost any form of non-conformism. Then, the next question is to set boundaries in a such a way as not to read anything as a manifestation of independent thinking or conflicting action. Although this is inevitably subject of interpretation, it is nonetheless context-dependent and this offers a flexible reading key. The following example can make things clearer. With the occasion of Nicolae Ceaușescu's birthday, usually pretext for exhibiting the cult of personality, some students in Romania published on the front page of the university magazine they edited a painting of the leader with his wife knocking glasses with the medieval ruler Stephan the Great who was coming out from a hanging portrait to personally greet his remote descendants. ${ }^{19}$ The

14 Tőkés, Rudolf (Ed.): Opposition in Eastern Europe, Baltimore, The Johns Hopkins University Press, 1979; Schöpflin, George: Politics in Eastern Europe, 1945-1992, Oxford, Blackwell, 1993.

15 Petrescu, Dragoș: Explaining the Romanian Revolution of 1989: Structure, Culture, and Contingency, Bucharest, Editura Enciclopedică, 2010.

16 Petrescu, Cristina: From Robin Hood to Don Quixote: Resistance and Dissent in Communist Romania, Bucharest, Editura Enciclopedică, 2013.

17 Geertz, Clifford: The Interpretation of Cultures, New York, Basic Books, 1973; Burke, Peter: What is Cultural History?, Cambridge, Polity Press, 2019.

18 Jarausch, Konrad H.: Dictatorship as Experience: Towards a Socio-Cultural History of the GDR, New York, Berghahn, 1999.

19 Dialog, Vol. 15, No. 1 (January 1983), p. 1; Cristina Petrescu, “'Free Conversations in an Occupied Country:' Cultural Transfer, Social Networking, and Political Dissent in Romanian Tamizdat,” in Friederike Kind-Kovács and Jessie Labov (Eds.) Samizdat, Tamizdat and Beyond: Transnational Media During and After Socialism, New York, Berghahn, 2013, p. 107-136; Antonesei, Liviu: “Dan Hatmanu a murit, Dumnezeu să-1 ierte!” (Dan 
painting could be interpreted as ridiculing Ceaușescu's mania to see himself as a follower of all great historical rulers of Romania, but the painter actually intended it as an homage to the leader. Moreover, Ceaușescu liked it, as he was unable to see the kitsch in it, and rewarded the author, who became deputy in the Grand National Assembly, the fake communist parliament. ${ }^{20}$ However, once students started to trumpet around the city that their intention was a mockery not a flattery, then the secret police arrested them, searched their houses, confiscated their books, cross-examined their entourage, put all under surveillance and forced the removal of the editorial team from the university magazine. ${ }^{21}$ In short, the distancing from the official system of meanings might not be explicit, but it must be either intentional or perceived as such, in particular by the secret police.

This switches the discussion from the working definition that widens research and thus creates new knowledge to the question of the new sources, the collections, which could include a wide variety of items, ranging from art works to everyday objects, from visual images to written documents, from memorabilia to musical records. First, it must be emphasized that not all forms of thought and action illustrating a discernible variation from the imposed system of meanings could be documented through the existence of a collection of material or digital items. Independent thinking or conflicting action were more often than not personal experiences which have been preserved only because their practitioners shared memories retroactively, after the regime change. This is the case in Romania of the so-called "resistance through culture," which bears a striking resemblance with cultural opposition. However, it produced not only more collaborators with the secret police than resisters, but also nothing beyond justificatory recollecting arguments. ${ }^{22}$ The purpose of "resistance through culture" was to avoid "the systematic and total destruction of culture, sticking to the idea that only the spirit can ensure the survival of a historically menaced country," 23 one practitioner claims. There is a self-ironical reply that implies the retroactive, post-1989 definition and the lack of evidence: "We were good professionals. (...) We were not against institutions in a militant way, but we did our best to remain in their shadow. (...) Later we found out that this was 'resistance through culture.' At the time, we did not know." ${ }^{24}$ In contrast, the project focused on evidence, on collections preserving traces of past acts or discourses that illustrate the existence of a critical, alternative, independent thinking in relation to

Hatmanu passed away, God forgive him!, 27 December 2018, https://antoneseiliviu.wordpress.com/2018/12/27/ dan-hatmanu-a-murit-dumnezeu-sa-1-ierte/

20 "Pictorul Ceauşeştilor primeşte titlul de excelenţă pentru întreaga activitate" (Ceaușescu's painter receives honours for life-time activity), Adevărul de Iaşi, 29 November 2011; https://adevarul.ro/locale/iasi/pictorul-ceausestilor-primeste-titlul-excelenta-intreaga-activitate-1_50ad8b987c42d5a6639715a2/index.html

21 Petrescu, Dan and Liviu Cangeopol, Ce-ar mai fi de spus: Convorbiri libere într-o ţară ocupată (What remains to be said: Free conversations in an occupied country (new and rev ed), Bucharest, Nemira, 2000.

22 Petrescu, Cristina: "Concebir Europa desde el oltro lado del Telón de Acero: Intelectuales rumanos y centroeuropeos en comparación,” Ayer, Vol. 82, No. 2 (2011), pp. 55-86; Petrescu, Dragoș: “The Resistance That Wasn't: Romanian Intellectuals, the Securitate, and the 'Resistance through Culture'," in Joachim von Puttkamer, Stefan Sienerth and Ulrich A. Wien (Eds.): Die Securitate in Siebenbürgen, Cologne, Böhlau Verlag, 2014, pp. 11-35.

23 Liiceanu, Gabriel: Jurnalul de la Păltiniş: Un model paideic în cultura umanistă (The Păltiniş diary: A paideia-like model in the humanistic culture), Bucharest, Humanitas, 1990, pp.13-14.

24 Mihăilescu, Vintilă: “Ăştia eram noi” (These were we), in Călin-Andrei Mihăilescu (Ed.), Cum era? Cam aşa...: Amintiri din anii comunismului [românesc] (How was it? Something like that...: Memories from the years of [Romanian] communism), Bucharest, Curtea Veche, 2006, p. 18. 
the system of ideas and values imposed by the party state at a given moment, since these are subject of recurrent changes.

How can one identify such collections that constitute sources for the study of the wider range of manifestations of non-conformism than open dissent? There are two ways of pursuing research. One is to identify individuals and groups, beginning with those already canonized, and search if there is an institution preserving a collection with material or digital items demonstrating their endeavours to critically assess the official worldview and act according to their independent minds. The other way is to identify types of activities that were formally prohibited, de-facto marginalized, informally tolerated or even supported activities that conflicted partly with the official system of meanings, then discover individuals and groups involved, and finally their hitherto unknown collections, usually preserved outside institutions. The collections could be found in state institutions only in as much the individuals or groups behind were tolerated by the former regime. In contrast, independent institutions, such as those run by different religious denominations or private museums that emerged after 1989, actually highlight collections illustrating anti-communism. Many of such collections returned from the exile, and testify for the transnationality of domestic non-conformism, which could not have emerged and survived without entangling with the diaspora. These collections could be a separate assembly of items, preserved for their historical significance as part of the cultural heritage, but they could be part of larger collections, created with a different purpose than to preserve valuable traces of non-conformism. The latter are the so-called ad hoc collections, which the COURAGE researchers redefined by selecting only those items which fit the working definition. This is primarily, yet not exclusively, the case of the ad hoc collections from the former secret police archives, the Securitate. ${ }^{25}$

While the overall purpose of the project was to discover new sources and create new knowledge about communist dictatorships, in general, and the opposition to these regimes, in particular, it was the research on the Romanian case that reframed the old interpretations and suggested new narratives about European identity. First, the initial disadvantage of covering a country with so few individuals challenging Ceaussescu's ruthless dictatorship proved to be a blessing in disguise, because researchers had to pursue mostly the above-mentioned second path towards collections. As mentioned, this starts from types of activities to find individuals or groups and finally their unknown private collections. Thus, research on Romania resulted in the discovery of a consistent number of fresh sources for understanding the experience of living under a communist dictatorship, which were created not by already canonized heroes of the recent past, but by common individuals involved in cultural activities in the largest possible meaning. Second, in as much as researchers followed the first path which leads to collections preserved by institutions, the largest majority of findings were in the archives of the former secret police. Obviously, these archives did not reflect the cultural heritage of dissent, but the bureaucratic

25 Faraldo, José M.: Las redes del terror. Las policías secretas comunistas y su legado, Barcelona, Galaxia Gutenberg, 2018; Petrescu, Dragoș: "Dealing with the Securitate Files in Post-communist Romania: Legal and Institutional Aspects," in Florian Kührer-Wielach and Michaela Nowotnik (Eds.) Aus den Giftschränken des Kommunismus: Methodische Fragen zum Umgang mit Überwachungsakten in Zentral-und Südosteuropa, Regensburg, Verlag Friedrich Pustet, 2018, pp. 43-60. 
purposes and the institutional mission of this infamous institution of surveillance. ${ }^{26}$ However, their very existence allowed an interesting comparison with the collections created by those kept under surveillance and highlighted one more time that dictatorships used the secret police against citizens and not in their service. ${ }^{27}$ Third, the communist regime in Romania, unlike in other countries of East-Central Europe, was also nationalist in its latest phase..$^{28}$ Thus, the opposition to this regime was fundamentally democratic and anti-nationalist, while the related collections implicitly reflect values and ideas compatible with those on which the European Union was founded: rule-of-law, human rights, civil liberties, etc. To sum up, focusing on the particular Romanian case, while constantly employing an asymmetrical comparison with the other countries in East-Central Europe, this author highlights a new sense of being European experienced by many ordinary individuals who created everyday meanings and cultural practices as if they lived in a free country. ${ }^{29}$

\section{Searching for collections}

Since the aim of the COURAGE project in Romania was expanding the existing canon, not building an alternative, its starting point was the already established canon of remembering the openly confrontational discourses and activities that led to direct collisions with the communist authorities. This category refers primarily to political dissent, which in this country found manifestation in two separate waves: first immediately after the communist takeover and then prior to the regime change. ${ }^{30}$ In the methodological framework of the project, the former category is reflected in collections created after 1989 in the purpose of preserving the memory of the innocent victims of the repression and of those who organized armed resistance in the mountains in the hopes of carrying on guerrilla warfare. ${ }^{31}$ Several collections of oral history interviews conserve this significant part of the collective memory, which began crystallizing itself during the first stage of the post-1989 transition, when the

26 Verdery, Katherine: My Life as a Spy: Investigations in a Secret Police File, Durham, NC, Duke University Press, 2012; Idem, Secrets and Truths: Ethnography in the Archive of Romania's Secret Police, Budapest, Central European University Press, 2014.

27 Ash, Timothy Garton: The File: A Personal History, New York, Random House, 1997; Petrescu, Dragoș: "Closely Watched Tourism: The Securitate as Warden of Transnational Encounters, 1967-69," Journal of Contemporary History, Vol. 50, No. 2 (April 2015), 337-353.

28 Jowitt, Kenneth: Revolutionary Breakthroughs and National Development: The Case of Romania, 1944-1965, Berkeley, University of California Press, 1971; Gilberg, Trond: Nationalism and Communism in Romania: The Rise and Fall Ceauşescu's Personal Dictatorship, Boulder, CO, Westview Press, 1990; Petrescu, Dragoș: "Building the Nation, Instrumentalizing Nationalism: Revisiting Romanian National-Communism, 19561989," Nationalities Papers, Vol. 37, No. 4 (July 2009), pp. 523-544.

29 Petrescu, Dragoș: "Conflicting Perceptions of Western Europe: The Case of Communist Romania, 1958-1989" in José M. Faraldo, Paulina Gulińska-Jurgiel and Christian Domnitz (Eds.) Europa im Ostblock: Vorstellungen und Diskurse, 1945-1991, Cologne, Böhlau Verlag, 2008, pp. 199-220.

30 Deletant, Dennis: Romania under Communism: Paradox and Degeneration, New York, Routledge, 2019; Petrescu, Cristina and Dragoș Petrescu: "The Canon of Remembering Romanian Communism: From Autobiographical Recollections to Collective Representations," in Maria Todorova, Augusta Dimou and Stefan Troebst (Eds.) Remembering Communism: Private and Public Recollections of Lived Experiences in Southeast Europe, Budapest, Central European University Press, 2014, pp. 43-70.

31 Ciobanu, Monica: "Reconstructing the History of Early Communism and Armed Resistance in Romania," Europe-Asia Studies, Vol. 66, No. 9 (October 2014), pp. 1452-1481; Idem, Repression, Resistance and Collaboration in Stalinist Romania, 1944-1964: Post-communist Remembering, London \& New York, Routledge, 2020. 
open discussions on a formerly taboo topic such as the crimes of the communist regime marked the break with the non-democratic past and gave expression to the desire to build a democratic future. ${ }^{32}$ Of such collections, of prime importance are those of the Sighet Memorial, which preserves not only oral testimonies, but also an impressive number of artefacts gathered by public collect and displayed in a former place of detention for political prisoners that became a major site of remembrance. ${ }^{33}$ In 2018, it received the European heritage label in recognition of its contribution to the understanding of the values Europe stands for, i.e., rule-of-law, human rights, civil liberties, etc., by preserving the memory of those innocent individuals who lost their lives because the Soviet-style dictatorships rejected these values. It is a place that reminds that all non-democratic regimes, left and right, had turned against part of their citizens by defining them on an arbitrary basis as the inimical "other." This realm of memory is not competing but complementing the sites memorializing the Holocaust or other genocides in Europe, as all remind of the criminal nature of all dictatorships. ${ }^{34}$ As for political dissent prior to the regime collapse, the most significant collection is the Memorial of the Revolution in Timișoara. This collection of artefacts related to the popular revolt of 1989, which first emerged in, and then spread from, this city to Bucharest, ultimately leading to the regime change, was also gathered by public collect. ${ }^{35}$ This memorial with its collections is a place of remembrance which highlights that the communist regimes never ceased to use violence against citizens; in the case of Romania, the Revolution of 1989 resulted in 1,100 deaths and 3,300 casualties. It is a realm of memory that commemorates people who fought for liberty and lost their lives at a time when liberty was taken for granted in most European countries. It is a place that reminds everyone that some people considered the 1989 East-Central European dream of "returning to Europe" worth dying for. ${ }^{36}$

Prior to the unexpected collapse of communism, open confrontations and direct collisions with the Romanian communist regime represented individual endeavours

32 Ciobanu, Monica: “Teaching History and Building a Democratic Future: Lessons from Post-communist Romania," Democracy and Education, Vol. 17, No. 3 (2008), pp. 58-62; Petrescu, Cristina and Dragoș Petrescu, "Retribution, Remembering, Representation: On Romania's Incomplete Break with the Communist Past," in Gerhard Bessier and Katarzyna Stokłosa (Eds.): Geschichtsbilder in den postdiktatorischen Ländern Europas: Auf der Suche nach historisch-politischen Identitäten, Berlin, Lit Verlag, 2009, pp. 155-182; Mitroiu, Simona: "Recuperative Memory in Romanian Post-Communist Society," Nationalities Papers, Vol. 44, No. 5 (2016), pp. 751-771; Rusu, Mihai Stelian: "Transitional Politics of Memory: Political Strategies of Managing the Past in Post-communist Romania,” East-Europe Asia Studies, Vol. 69, No. 8 (2017), pp. 1257-1279.

33 Raţiu Alexandru et al.: Memoria inchisorii Sighet (The memory of the Sighet prison), Bucharest, Fundaţia Academia Civică, 2003; Rusan, Romulus: Cronologia şi geografia represiunii comuniste din România: Recensămîntul populaţiei concentraţionare, 1945-1989 (Chronology and geography of communist repression in Romania: A census of detained population, 1945-1989), Bucharest, Fundaţia Academia Civică, 2007; Idem, Istorie, memorie, memorial sau Cum se construiește un miracol (History, memory, memorial or How to build a miracle), Bucharest, Fundația Academia Civică, 2017.

34 Petrescu, Cristina and Dragoș Petrescu, “The Pitești Syndrome: A Romanian Vergangenheitsbewältigung?,” in Stefan Troebst (Ed.) Postdiktatorische Geschichtskulturen im Süden und Osten Europas: Bestandsaufnahme und Forschungsperspektiven, Göttingen, Wallstein, 2010, pp. 502-618.

35 Vasile-Szabo, Lucian: O revoluție, un memorial... (One revolution, one memorial...) Timișoara, Editura Partoș, 2010; Rado, Gino and Lucian-Vasile Szabo: Revoluția de la Timișoara din decembrie 1989 pe ințelesul tuturor (The revolution of December 1989 in Timișoara in everybody's language), Timișoara, Editura Memorialul Revoluției, 2016.

36 Petrescu, Dragoș: Entangled Revolutions: The Breakdown of the Communist Regimes in East-Central Europe, Bucharest; Editura Enciclopedică, 2014; Idem, "Eine unerwartete Revolution:1989 in Rumänien und die Folgen," Religion und Gesellschaft in Ost und West, Zürich, No. 9 (September 2019), pp. 24-26. 
more than collective protests, and they were usually met with harsh repressive measures by the secret police. ${ }^{37}$ The strongest collective act against Ceaușescu's regime is that of the so-called Goma Movement, which generated a substantial collection of documents in the former secret police archives, updated the methods of surveillance and control to lead to the quick dismemberment of this emerging movement for human rights. ${ }^{38}$ As for individual cases of defiance, a few private collections preserved by former dissidents are worth mentioning, most notably by Doina Cornea ${ }^{39}$ and Éva Gyimesi-Cseke ${ }^{40}$, to refer only to two examples of prominent female personalities who managed to defy Ceaușescu's regime politically for years. Both constitute rare cases when private collections created by individuals challenging the official system of meanings can be compared with the collections created by the secret police about them. Under Romanian law, a specialized institution was created in 1999 under the name the National Council for the Study of the Securitate Archives (Romanian acronym CNSAS), and entrusted with the preservation, screening, and study of the Securitate documents. As most former political dissidents preserved almost nothing of their activities, today only the CNSAS collections include evidence about their oppositional activities. ${ }^{41}$ However, more often than not, evidence that can define a collection according to the logic of the project is scattered in different CNSAS collections, because the archiving logic of the secret police has been preserved by the new institution in the purpose of fulfilling its prime mission of unmasking collaborators. ${ }^{42}$ At the same time, the secret police destroyed the files of many dissidents ${ }^{43}$, so their open confrontations and direct collisions with the former dictatorial regime can be reconstructed only from collections created by diaspora, which highlight the pre1989 transnational networks of support. ${ }^{44}$ Most of these collections returned to Romania after 1989. A first category was created by members of the exile who worked

37 Deletant, Dennis: Ceaușescu and the Securitate: Coercion and Dissent in Romania, 1965-1989, London, Hurst, 1995; Rusan, Romulus (Ed): Cei care au spus NU: Oponenţi şi disidenţi din anii '70 şi '80 (Those who said NO: Opponents and dissidents of the 1970s and 1980s), Bucharest, Fundaţia Academia Civică, 2005; Petrescu, Cristina and Dragoș Petrescu, "Dissidenten im Kommunistischen Rumänien: Kritik, Handlungsstrategien und Selbsgestellte Aufgaben, 1977-1989," in Wolfgang Eichwede and Jan Pauer (Eds.): Ringen um Autonomie: Dissidentendiskurse in Mittel-und Osteuropa, Berlin, Lit Verlag, 2017, pp. 309-356.

38 Goma, Paul: Culoarea curcubeului '77: Cutremurul oamenilor. Cod "Bărbosul:” Din dosarele Securităţii, 1957-1977 (The colour of the rainbow 1977: The earthquake of people. Code-name "Bearded Man:” From the files of the Securitate, 1957-1977), Iaşi, Polirom, 2005; Petrescu, Cristina: "The Goma Movement, Forty Years After: Controversies, Amnesia and (Mis)Canonization,” Arhivele Totalitarismului, Vol. 15, No. 3-4 (2017), pp. $130-151$.

39 Cornea, Doina: Scrisori deschise şi alte texte (Open letters and other texts), Bucharest, Humanitas, 1991; Idem, Liberté? Entretiens avec Michel Combes, Paris, Criterion, 1990; Idem, Jurnal: Ultimele caiete (Diary: The last notebooks), Bucharest, Editura Fundaţiei Academia Civică, 2009.

40 Cseke-Gyimesi, Éva: Gyöngy és homok: Ideológiai értékjelképek a magyar irodalomban (Pearls and sand: Ideological value-symbols in Hungarian literature), Bucharest, Kriterion, 1992; Idem, Szem a láncban: Bevezetés a szekusdossziék hermeneutikájába (Piece in a chain: Introduction to the hermeneutics of Securitate files), Cluj-Napoca, Komp-Press - Korunk, 2009.

${ }_{41}$ Tudoran, Dorin: Eu, fiul lor: Dosar de Securitate (I, their son: A Securitate file), Iași, Polirom, 2010.

42 Petrescu, Cristina: "The Afterlife of the Securitate: On Moral Correctness in Post-Communist Romania," in Maria Todorova, Augusta Dimou and Stefan Troebst (Eds.): Remembering Communism: Private and Public Recollections of Lived Experiences in Southeast Europe, Budapest, Central European University Press, 2014, pp. 385-416.

43 Müller, Herta: Cristina und ihre Attrappe oder Was (nicht) in den Akten der Securitate steht), Göttingen, Wallstein, 2009.

44 Kind-Kovács, Friederike: Written Here, Published There: How Underground Literature Crossed the Iron Curtain, Budapest, Central European University Press, 2014. 
for the Romanian desks of Western broadcasting agencies, such as Radio Free Europe or Voice of America, and mostly duplicated documents from the archives of these institutions. As these archives were either successively reorganized or completely destroyed, these private collections, which in the meantime were donated to Romanian public institutions, are often preserving unique documents. ${ }^{45}$ Another category was created by those who supported publications, organizations, and associations of the exile community, which in the largest majority are held in the custody of a specialized post-1989 institution, the Institute for the Study of the Communist Crimes and the Memory of the Exile. ${ }^{46}$

Following the working definition to go beyond these already known cases of open confrontation and direct collision with the communist regime, the project discovered a wide range of forms of non-conformism among people active in various professions and occupations. These were tolerated and even supported types of opposition, which included alternative forms of thinking and acting that only partially conflicted with the official views. Their practitioners were able to survive professionally and even get support by presenting their endeavours as fully in compliance with the value system of the regime in that given moment and downplaying the aspects that might have been inconvenient. Representatives of this category carried out a wide spectrum of cultural oppositional activities, ranging from literary works which bypassed censorship to samizdat and tamizdat publications, from visual arts to independent journalism, and from religious activism to folk culture. They followed different strategies of by-passing the system to pursue an internationally recognized professional career. The most radical form was to ignore completely the state institutions and live as a freelance intellectual, as reflected in a life-time collection of books, manuscripts and correspondence gathered by the literary critic Adrian Marino, who survived professionally after his release from prison without any institutional affiliation. ${ }^{47}$ This was possible due to the transnational connections which he maintained in order to get support for scholarships or backing for publication abroad and, sadly, the instrumental help of the secret police, which allowed him to travel outside Romania in exchange of providing information, while others never received an exit visa. ${ }^{48}$

Beside such unusual case of free-floating intellectual, there were the artistic and creative occupations which enjoyed greater freedom of expression than those which required regular employment in a state institution. In communist Romania, writers, artists, composers and cinematographers were organized in professional associations which were responsible for organizing the distribution and retribution of their works. For example, the Writers' Union paid royalties for the published books but also ad-

45 Bernard, Noel: Aici e Europa Liberă (This is Radio Free Europe), Bucharest, Tinerama, 1991; Mircea Carp, "Vocea Americii” în România, 1969-1978 ("Voice of America" in Romania, 1969-1978), Iaşi, Polirom, 1997; de Flers, René Al.: Radio "Europa Liberă” şi exilul românesc: O istorie încă nescrisă (Radio Free Europe and the Romanian exile: A still unwritten history), Bucharest, Vestala, 2005.

46 Dumitrescu, Vasile C.: O istorie a exilului românesc, 1944-1989 (A history of the Romanian emigration, 19441989), Bucharest, Editura Victor Frunză, 1997; Manolescu, Florin: Enciclopedia exilului literar românesc, 1945-1989: Scriitori, reviste, instituţii, organizaţii (The encyclopedia of the Romanian literary exile, 19451989: Writers, review, institutions, organizations), Bucharest, Compania, 2003.

47 Marino, Adrian: Viaţa unui om singur (The life of a lonely man), Iaşi, Polirom, 2010.

48 Marino, Adrian: ¡Ole! España, Bucharest, Editura Eminescu, 1974; Idem, Carnete europene (European notebooks), Cluj-Napoca, Dacia, 1976; Andreescu, Gabriel: Cărturari, opozanţi şi documente: Manipularea Arhivei Securităţii (Scholars, opponents and documents: The manipulation of the Securitate archives), Iaşi, Polirom, 2013. 
ministered a special fund from which writers could contract huge loans. Thus, many writers willingly produced works consistent with the official nationalist-communist ideology as formulated by Ceaușescu's famous Theses of July 1971, which required art and culture to disentangle from Western models. However, many others resisted the temptation to comply and tried their best to maintain their independent thinking and their connections with literary and artistic trends abroad. This was easier for people who belonged to the German minority, as they not only used a different language, but also drew inspiration from contemporary Austrian and German literature, as the collaborators of the secret police contributing to the CNSAS collections of today demonstrate too. ${ }^{49}$ In contrast, Romanian writers who tried to resist conformism just practiced a strategy of writing phrases with double meanings, which apparently were banal, but which could also be read as critical statements about the communist regime and its policies. The epitome of this strategy was Ana Blandiana's poem for children entitled "Arpagic," seemingly about a tomcat that was praised and applauded by everyone on his street, in which astute readers could recognize a skilfully disguised criticism of Ceaușescu's personality cult. ${ }^{50}$ Authors struggled to write books with hidden meanings to bypassed censorship, but more often than not these were withdrawn from bookshops after their messages were decoded for the secret police, usually by colleague-writers. Some were confiscated before publication, and the CNSAS has an entire collection of manuscripts that never got published ${ }^{51}$, while many private books collections include the rare editions that were sold only for a few days before interdiction. Today, these encrypted meanings are meaningless to younger generations, so why authors who always dream of eternal recognition engaged in this risky adventure? The publication of these non-conformist books was supported by the creation of a parallel canon by literary critics in exile through programs at Radio Free Europe. ${ }^{52}$ Their role in offering an alternative legitimacy to those whom the regime marginalized is illustrated by the collections of their broadcastings, created in Paris and now preserved in the National Archives of Romania. ${ }^{53}$

As compared to collections related to literature, art collections that could be associated with a form of cultural opposition were rarer. The official market for such works was regulated by the Artists' Union, which paid the authors whose works

49 Totok, William: Constrîngerea memoriei, Insemnări, documente, amintiri (The constraint of memory: Notes, documents, memories), Iaşi, Polirom, 2001; Petrescu, Cristina: "Deutscher sein in Ceauşescus Rumänien: Aktionsgruppe Banat und ihre Rekonstruktion der eigenen Vergangenheit," in Gerhardt Csejka and Stefan Sienerth (Eds.): Vexierspiegel Securitate: Rumäniendeutsche Autoren im Visier des kommunistischen Geheimdienstes, Regensburg, Friedrich Pustet Verlag, 2015, pp. 67-85; Idem, “Archive and Memory: Herta Müller's Entanglements with the Communist Power," in Pia Janke and Teresa Kovacs (Eds.): Schreiben als Wiederstand: Elfriede Jelinek \& Herta Müller, Vienna, Praesens Verlag, 2017, pp. 353-367.

50 Blandiana, Ana: Intîmplări de pe strada mea (Occurrences on my street), Bucharest, Editura Ion Creangă, 1988.

51 Pițu, Luca: Artelul Textual - "Brazde peste haturi” revisited: Pagini salvate dintr-un samizdat colectiv (The textual [c]artel - "Plough cuts over land-plot borders" revisited: Saved pages from a collective samizdat), Iași, Editura Opera Magna, 2011.

52 Lovinescu, Monica: Unde scurte (Short waves), 5 vols., Bucharest, Humanitas, 1990-1995); Ierunca, Virgil: Românește (Romanian style), Bucharest, Humanitas, 1991; Idem, Dimpotrivă (On the contrary), Bucharest, Humanitas, 1994.

53 Stan, Snejana Lavinia: Exilul românesc în Europa occidentală în anii 1970-1980: Politica prin cultură (Romanian exile in Western Europe during the 1970s and 1980s: Politics through culture), Cluj-Napoca and Gatineau, Argonaut and Simphologic Publishing, 2013; Meseșan, Anarela: Exilul românesc din perioada comunistă reflectat în fondul bibliotecii de la Paris a familiei Monica Lovinescu-Virgil Ierunca (Romanian exile of the communist period reflected in Monica Lovinescu-Virgil Ierunca personal library in Paris), Cluj-Napoca, Centrul de Studii Transilvane, 2015. 
had been accepted and then distributed these works to museums all across Romania. Because of this quota system and the systematic marginalization of avantgarde or experimental works, there are too few contemporary art objects in the same institution to form a collection. The Art Museums in Timișoara ${ }^{54}$ and Brașov ${ }^{55}$ are among the exceptions due to the existence of local non-conformist artists whose works were donated and preserved as such, mostly because these did not confront directly the communist aesthetics. The post-communist Museum of Contemporary Art in Bucharest could only retrospectively reunite many of the works of art which were kept on the periphery under communism. ${ }^{56}$ Private contemporary art collections were far more difficult to create due to the price barrier. Yet, worth mentioning is the collection created by the medical doctor Sorin Costina in a remote city from the Apuseni Mountains, a synecdoche of contemporary art created in communist Romania and a last refuge for many non-conformist artists excluded from museums. ${ }^{57}$ Other types of visual arts, which were less costly because they were easier to duplicate or make in many copies (such as drawings and caricatures) survived more easily in the collections of their creators. Perhaps the most notorious are the collections preserved by Imre Baász, an illustrator who chose experimentalism to refresh the dogmatic art of the communist period ${ }^{58}$, and by Mihai Stănescu, a caricaturist who is known beyond Romania's borders due to his witty drawings which captured the absurdity of Ceaussescu's policies..$^{59}$ Even less significant was the production of non-conformist films. In fact, only four cinematic narratives are known to have been banned in communist Romania, two of them by the same director, Lucian Pintilie, and paradoxically, three in the $1980 \mathrm{~s}^{60}{ }^{60}$ Thus, an activity in theatre and film as that of the above-mentioned most interdicted and simultaneously most internationally acclaimed Romanian director of the time is reflected only in collections assembled from secret police files. ${ }^{61}$

Compared to the artistic and creative occupations, professions which required full employment in a state institution had even fewer liberties. Professionals in these fields could only take advantage of the inconsistencies in the official views to pursue their research interests. They sometimes even received supplementary financial support from the local authorities, which had more liberty than the central authorities. Among the collections which reflect this type of bargaining are those preserved, for instance, by the ASTRA Museum in Sibiu. They include documentation about

54 Kessler, Erwin: Ştefan Bertalan: Emigrarea interioară (Ştefan Bertalan: The inner refuge), Bucharest, Vellant, 2016; Tulcan, Doru: Grupul Sigma: O perspectivă (The Sigma Group: A perspective), Timișoara, Triade, 2003.

55 Almási, Tibor: The Other Mattis-Teutsch, Györ, Régió Art Publishig House, 2001.

56 Cârneci, Magda: Artele plastice în România, 1945-1989 (The plastic arts in Romania, 1945-1989), Iași, Polirom, 2013; Preda, Caterina: Art and Politics under Modern Dictatorships: A Comparison of Chile and Romania, New York, Palgrave Macmillan, 2017.

57 Kessler, Erwin: Sorin Costina: Ucenicie printre arte (Sorin Costina: Apprenticeship among arts), Bucharest, Vellant, 2017.

58 Chikán, Bálint: Baász, Budapest, Szabad Tér, 1994.

59 Stănescu, Mihai: Umor 50\% (Humor 50\%), Bucharest, Uniunea Artiștilor Plastici din R. S. România, 1985; Idem, "Acum nu e momentul..." ("Now it is not the time..."), Bucharest, Uniunea Artiștilor Plastici din România, 1990.

60 Pintilie, Lucian: Reconstituirea (Reenactment, 1968, 1h 40min); Idem, De ce trag clopotele Mitică (Why are the bells tolling?, 1981, 2h 20min); Dan Pița, Faleze de nisip (Sand cliffs, 1983, 1 h 37 min; Nicolae Oprițescu), Sezonul pescăruşilor (The seagull season, 1985, 1h 47min).

${ }^{61}$ Rîpeanu, Bujor; Cinematografiștii: 2345 Cineaști, actori, critici și istorici de film și alte persoane (Cinematographers: 2345 directors, actors, critics and film historians and other persons), Bucharest, Meronia, 2013. 
the rural cultural heritage that was saved from the total destruction, to which the modernization drive of the communist regime condemned it, by presenting to state officials the remnants of the peasant architecture as landmarks of national identity. Masking their professional interests in the nationalist arguments which the regime promoted, ethnographers were able to bend the system and pursue activities which can be evaluated as forms of cultural opposition against the distorted communist version of modernization..$^{62}$ In the same category is the collection related to the restoration of the so-called Black Church, which is held in the Library and Archive of this parish community in Braşov. This collection tells the complex story of a Gothic monument of tremendous significance to the collective identity of the Saxon community in Transylvania, which was restored to its former glory under communism despite the atheist system of values and the policy of so-called of "systematization of urban and rural settlements." The latter meant massive demolitions in urban areas, including the razing of Romania's historical and architectural heritage, and it hit many cities hard, above all Bucharest, where professionals reacted by carrying out an unusual activity of cultural opposition: the relocation of churches to less visible locations. This operation saved several historical monuments from total destruction and required considerable inventiveness on the part of the engineers, who found a way not to disobey orders directly, but rather to moderate their consequences by proposing tolerated solutions. ${ }^{63}$

The demolitions in Bucharest and other cities also triggered the most significant activity of passive clandestine resistance to Ceaușescu's absurd policies. Unlike professionals who tried to bend the rules from the inside of the state institutions, those who pursued this type of cultural opposition opted for a dual strategy, a kind of Dr. Jekyll and Mr. Hyde approach. While pursuing their professional careers within tolerated boundaries, they acted in their spare time independently and immortalized on photo, film, or in paintings historic monuments that were about to be destroyed. This kind of resistance is illustrated by the photograph collection of historian Alexandru Barnea, which includes images of vanished urban landscapes and demolition sites, or the watercolours collection of architect Gheorghe Leahu, which preserves the owner's works capturing architectural landmarks and ordinary streets of Bucharest before completely razed. ${ }^{64}$ In fact, most professionals in the fields of history or the social sciences adopted the same kind of dual strategy. The most interesting example, due to its post-communist immense societal impact, is the private collection of oral history, which sociologist Zoltán Rostás has created. This collection illustrates the transformation of a passion that developed before 1989 in the grey zone of tolerance into a profession after 1989. His interviews, which capture the multicultural dimension of Bucharest, were conducted outside the world of his daily job, and he

62 Ronnås, Per: Urbanization in Romania: A Geography of Social and Economic Change since Independence, Stockholm, The Economic Research Institute, Stockholm School of Economics, 1984; Kligman, Gail and Katherine Verdery: Peasants under Siege: The Collectivization of Romanian Agriculture, 1949-1962, Princeton, Princeton University Press, 2011; Streza, Marius-Florian and Lucian Nicolae Robu (Eds.): Cornel Irimie şi evoluţia Muzeului Tehnicii Populare (Cornel Irimie and the evolution of the Museum of Folk Technics), 2 vols., Sibiu, ASTRA Museum, 2013.

63 Giurescu, Dinu C.: The Razing of Romania's Past, Washington, DC, The Preservation Press, 1989.

64 Leahu, Gheorghe: Bucureşti-arhitectură şi culoare (Bucharest-Architecture and colour), Bucharest, Editura Sport Turism, 1988; Idem, Bucureştiul dispărut (The lost Bucharest), Bucharest, Editura Arta Grafică, 1995; Idem, 1985-1989, Arhitect în "Epoca de Aur" (1985-1989, Architect during the "Golden Age"), Bucharest, Editura Fundația Academia Civică, 2013. 
had little or no hope of ever being able to use it to develop professionally, since the stories he collected contradicted the official homogenizing vision of the party state. Yet, this collection, which also preserved the memory of the school of sociology that was destroyed by the communist regime, made a decisive contribution to the institutionalization of oral history in post-1989 Romanian scholarly life. ${ }^{65}$

The collections created by representatives of the Hungarian community living in Romania deserve separate discussion for they altogether stand for the emergence of the global debate on minority rights as complementary to individual rights. While the official ideology always spoke of "Romanians, Hungarians, Germans, and other nationalities" as if they lived together in harmony, the quietly institutionalized policies of Ceaușescu's regime endangered the cultural reproduction of minority groups, in particular of the Hungarians living in Transylvania. ${ }^{66}$ It is often argued that anything created by the members of minority groups should be considered an act of cultural opposition to a communist regime that attempted to homogenize society by erasing cultural differences. However, as stated in the introduction, the COURAGE research in Romania considers only non-conformist discourses and activities that were also consistent with democratic values, and it applies this principle to the majority group of the Romanians, as well as to the minority groups. Accordingly, the two most noteworthy collections representing the community of the Hungarians in Transylvania are those illustrating the samizdat Ellenpontok (Counterpoints) and Kiáltó Szó (Screaming Word). Both collections are preserved by individuals who contributed decisively to their content and dissemination. The former is preserved in Gothenburg, in the private collection created by one of the founders of this underground publication. It comprises the largest number of items related to Counterpoints and the beginnings of the struggle to enlarge the concept of civil rights from a definition exclusively based on the individual to one that includes collective rights as a fundamental legal instrument in the protection of minority groups. ${ }^{67}$ The latter collection, which is preserved in Cluj-Napoca, represents a subsequent stage in this struggle for the recognition of minority rights as a tool against the discriminatory policies of Ceaușescu's regime.

The ethno-cultural diversity of Romania is also reflected in the diversity of its religious communities, which the communist regime did not openly persecute, with the exception of the suppression of the Greek Catholic community by forceful conversion to the Greek Orthodoxy. Church attendance, however, was heavily discouraged, so simple attendance at a Sunday mass and the organization of a baptism or a religious marriage represented non-conformist acts of the everyday life, which defied the atheist regime and had negative consequences for people's professional careers. The collections of cultural opposition corresponding to the Catholic or Calvinist denominations of the Hungarian minority are to be found either in the

65 Rostás, Zoltán: Monografia ca utopie: Interviuri cu Henri H. Stahl (Monograph as utopia: Interviews with Henri H. Stahl), Bucharest, Paideia, 2000; Idem, O istorie orală a Școlii Sociologice de la București (An oral history of the Sociological School of Bucharest), Bucharest, Printech, 2001; Idem, Chipurile orașului: Istorii de viață în București (Faces of the city: Life histories in Bucharest), Iași, Polirom, 2002.

${ }_{66}$ Schöpflin, George: Nations, Identity, Power: The New Politics of Europe, London, Hurst, 2000; Brubaker, Rogers: Nationalist Politics and Everyday Ethnicity in a Transylvanian Town, Princeton, Princeton University Press, 2006.

${ }_{67}$ Tóth, Károly Antal: Hol vagy, szabadság? Esszék, tanulmányok, vitaírások (Where are you, freedom? Essays, studies, pamphlets), Cluj-Napoca, Kriterion, 2015; Idem and Ilona Tóth, Egy szamizdat az életünkben: Az Ellenpontok (A samizdat in our lives: The Counterpoints), Cluj-Napoca, Kriterion, 2017. 
archives of the secret police or the archives of ecclesiastical institutions, such is the Áron Márton Collection from the Archiepiscopal Archives in Alba Iulia, or in the János Dobri Collection from the Archives of the Calvinist Parish Church of Dâmbul Rotund (Cluj). ${ }^{68}$ Similarly, the activities of the Lutheran community of the Germans in Romania are preserved in the collections held by the Teutsch Haus in Sibiu, as well as in the CNSAS Archives. ${ }^{69}$ As for assessing the resistance of the religious groups which are characteristic of the Romanian majority, including the clandestine activities of the suppressed Greek Catholics and the alternative groups created by the Greek Orthodox denomination ${ }^{70}$, there are no alternative repositories to trace their activities apart from those created by the secret police. These collections illustrate that many hierarchs tried to defend religious education against the atheist state, endeavoured to maintain rituals and conserve Church properties. In comparison, conspicuously absent are protests on the part of the hierarchs of the Romanian Greek Orthodox Church against the systematic destruction of their churches, which included fine examples of late medieval and early modern architecture. However, for many people, religion was an escape into a parallel world that survived on the periphery of the society and became central only at Easter and Christmas, which most individuals celebrated quietly with family members.

Parallel worlds of non-conformism existed for a limited time during holidays and more generally during people's spare time. The private collection preserved by journalist Andrei Partoș exemplifies the work of Radio Vacanța Costinești, a seasonal radio station, and its associated activity on the Black Sea coast, which represented a crucible of the alternative culture developed by the younger generation. This radio station, in fact an amplification station that only broadcast via loudspeakers within the bounds of Costineşti, a so-called youth resort, had only a limited audience, but this allowed broadcasting without prior censorship, which would have been obligatory routine procedure in a "normal" radio station. Diverse activities related to the theatre, film, music, and sports were held during the summer holidays in Costinești, and uncensored newspapers covered these events. The most peculiar of them were several highly unconventional competitions, including for instance an ironic contest which involved sitting for 48 hours on a post, which it is said to have been once won by one of the post-communist prime-ministers. This contest, as many others alike included in a book of records that is today the jewel of the above-mentioned collection, was a way of ridiculing the useless and faked communist records. In addition, clandestinely procured Western music made young people forget about restrictions in their everyday lives and act as if the communist regime did not exist. Interestingly, this seasonal activity was quietly supported by Ceauşescu's son, who preferred an

68 Buzogány, Dezső and Csongor Jánosi: A református egyház Romániában a kommunista rendszer első felében: Tanulmányok és dokumentumok. (The Reformed Church in the first half of the communist regime in Romania: Studies and documents), L’Harmattan, Budapest, 2011.

69 Pintilescu, Corneliu: “Conceptul de 'naţionalişti germani' în practica Securităţii, 1948-1989” (The concept of 'German nationalists' in the use of the Securitate, 1948-1989), in Vasile Ciobanu, Flavius Soloman and Sorin Radu (Eds.): Partide politice şi minorităţi naționale în secolul XX (Political parties and national minorities in the twentieth century), Cluj-Napoca, Kriterion, 2011, pp. 135-150.

70 Steinhardt, Nicolae: Jurnalul fericirii (Journal of blissfulness), Cluj-Napoca, Dacia, 1991; Calciu-Dumitreasa, Gheorghe: Şapte cuvinte către tineri (Seven words to the young), Bucharest, Anastasia, 1996; Gillet, Olivier: Religion et nationalisme: L'idéologie de l'Eglise orthodoxe roumaine sous le régime communiste, Brussels, Editions de l'Université de Bruxelles, 1997; Leuștean, Lucian N.: Orthodoxy and the Cold War: Religion and Political Power in Romania, 1947-65, New York, Palgrave Macmillan, 2009. 
alternative lifestyle and thus was present for, and supported many of, the activities in Costinești. ${ }^{71}$ Similarly, the mountains represented a space of liberty, where social conventions and political control ceased to exist for a while. The so-called Anonymous Mountaineer Collection of self-made escalade materials and other technical equipment for alpinism demonstrates the creativity of those who wanted to climb the mountains, but lacked the necessary items. As Romanian state factories did not produce equipment for leisure alpinism, but only for military purposes, people with a passion for climbing had to make a wide range of items, such as ice axes, crampons, and pitons, by copying Western catalogues and risking their lives with untested materials for the sake of a hobby which allowed them to feel free temporarily. ${ }^{72}$ Finally, the collection of VHS video cassettes preserved by the translator of 3000 pirated movies, Irina Margareta Nistor, shows how everyday spare time was transformed into a time of liberty. This collection reminds one of the Western films that were introduced clandestinely into Romania between 1985 and 1989 and which were then translated, dubbed and distributed on video cassettes (semi)clandestinely. This chain of activities emerged in reaction to the reduction of the official television program to just two hours per day and to news about Ceauşescu and the Romanian Communist Party. ${ }^{73}$ It is worth noting that this type of cultural opposition was lucrative, and this dissemination scheme allowed many to enrich themselves. It is also worth mentioning that this activity required the silent support of the secret police, without which such a large-scale endeavour could not have survived for several years. Thus, this collection exemplifies the tacit deals that existed among the people who were once engaged in acts that can be considered forms of cultural opposition and the representatives of the communist regime. ${ }^{74}$ Besides movies, Western music, in particular jazz, rock, punk, and other genres considered non-conformist in communist countries, symbolized the quest for crossing borders at least virtually. Several

71 Andrei Partoș, “Aveam microfon portabil, ieșeam pe terasă și vorbeam cu oamenii” (I had a portable microphone, I went out on the terrace and talked with people), Adevărul, 18 August 2009; http://adevarul.ro/entertainment/celebritati/andrei-partos-aveam-microfon-portabil-ieseam-terasa-vorbeam-oamenii-1_50ac9e3a7c42d5a66386efa7/index.html; Idem, “Amintiri din Epoca de Aur” (Memories from the golden age), Adevărul, 31 July 2010; http://adevarul.ro/entertainment/celebritati/andrei-partos-amintiri-epoca-aur-1_50ae70817c42d5a6639cba30/ index.html; Silviu Petcu, "Ni s-a ţinut spatele pe vremea lui Ceaşcă" (In Ceaușescu's time, our backs were protected), Evenimentul zilei, 31 May 2012; http://www.evz.ro/silviu-petcu-distractis-ni-s-a-tinut-spatele-pevremea-lui-ceasca-984354.html; Corina Cosmescu, "Altădată Costineștiul era o evadare" (Costineşti used to be an escape), Adevărul, 30 July 2013; http://adevarul.ro/entertainment/muzica/andrei-partos-costinesti-1_51f6db3ac7b855ff5685cb6b/index.html; Cristian Pătrășconiu, "Radio Vacanța Costinești: Magie, nostalgie, libertate" (Radio Vacanța-Costinești: Magic, nostalgia, freedom), LaPunkt, September 2015; http://www.lapunkt. ro/2015/09/01/radio-vacanta-costinesti-magie-nostalgie-libertate/; Sânziana Ionescu, "Un nou festival pe litoral: FolkFest Remember Costineşti, 25-26 august" (A new festival on the [Black] sea coast: FolkFest Remember Costinești, 25-26 August), Adevărul de Constanța, 27 June 2017; http://adevarul.ro/locale/constanta/ un-nou-festival-litoral-folkfest-remember-costinesti-25-26-august-1_5952824e5ab6550cb893bcb3/index.html

72 Baticu, Niculae: Jurnalul unui alpinist și aviator (The diary of an alpinist and aviator), Bucharest, România Pitorească, 2012; Kargel, Walter: Alpinism: Inălțimi, riscuri, bucurii (Alpinism: Heights, risks, joys), Bucharest, România Pitorească, 2012; Cristea, Emilian: Biblioteca montaniardului (The bookcase of the mountaineer), Bucharest, România Pitorească, 2015; Petrescu, Dragoș: "Fiecare om are verticala lui: Interviu cu Cristi Pătrășconiu" (Everyone has his/her own vertical: Interview with Cristi Pătrășconiu), LaPunkt, October 2018, https:/www.lapunkt.ro/2018/10/interviu-dragos-petrescu-fiecare-om-are-verticala-lui/

73 Călugăreanu, Ilinca: "VHS vs. Communism," New York Times, 17 February 2014, https://www.nytimes. com/2014/02/18/opinion/vhs-vs-communism.html; Gillet, Kitt: "The voice that brought Hollywood films to communist Romania's TV screens," The Guardian, 25 December 2014; https://www.theguardian.com/ world/2014/dec/25/hollywood-film-communist-romania-video-dub-irina-margareta-nistor.

74 Călugăreanu, Ilinca: Chuck Norris vs. Communism, 2015, 1h18min. 
private collections preserved the cultural diversity of youth subcultures that in Romania emerged around the late 1960s and early 1970s, while the official cultural policies of the regime became increasingly harsh, especially after their recodification in Ceaușescu's Theses of July 1971. LPs (semi)clandestinely imported to be multiplied on tapes, widely disseminated to be listened at private parties or posters and photographs related to (semi)underground concerts in exclusive student clubs testify to the ways in which spare time became a temporary moment of liberty. ${ }^{75}$

\section{Instead of conclusions}

The above cartography of collections reflecting non-conformist thoughts and actions is inevitably incomplete, but it suggests a large variety of under-researched activities that go much beyond the already canonized open dissent. The proposed concept of "cultural opposition" was not necessarily useful as such, but it did reframe research, uncovered new sources and generated new knowledge about living under communist dictatorships to finally suggest new narratives about grassroots experiences of European identity/ties. Research on Romania highlighted a polarized cluster of collections between two major categories: those created by the secret police keeping under surveillance these non-conformist activities and those created by the practitioners of alternativity, in their largest majority anti-heroes who preserve their own private collections. Since the latter were not in the canon of remembering communism in Romania, relevant institutions ignored their collections, while the owners are rather reluctant to donate and loose for ever the control over the posterity of their past endeavours. Thus, these private collections remain of very limited, primarily local interest, unless already digitized and disseminated via social media. In contrast, the CNSAS collections became nationally and internationally relevant, for they remind everyone that the communist past was "another country" in which the secret police existed to harass legally innocent but non-conformist individuals, the human and citizen rights were constantly violated, and the citizens could express their critical opinions only through underground media and street demonstrations. In other words, the secret police collections also highlighted in this project illustrate that the type of modernisation proposed by the communist regimes in East-Central Europe lacked the fundaments of modern Western democracies, i.e., mechanisms of limiting power, granting political representation, and guaranteeing basic rights. In addition, the private collections discovered by this project represent what one might call the silent agents of change. These individuals were not actively militant or instrumental in the regime change of 1989, but they passively re-Europeanized Romania from before 1989. Their previously unknown collections of material or digital items bear witness today to the diverse forms of critical thinking and action which were independent from the official and compulsory system of meanings. Neither heroes nor mere op-

75 Ionescu, Doru. Club A-42 de ani: Muzica tinerereții tale (Club A - 42 years: The music of your youth), Bucharest, Casa de Pariuri Literare, 2011; Udrescu, Mircea: Metronon '70: Cornel Chiriac în documentele Securității (Metronon '70: Cornel Chiriac in the Securitate's documents), București, Editura Universitară, 2015; Ionescu, Doru: Timpul chitarelor: Cornel Chiriac și Epoca Beat (The Time of Guitars: Cornel Chiriac and the Beat Epoch), Bucharest, Integral, 2016; Ionescu, Teodora: Folk pur și simplu (Folk pure and simple), Bucharest, Editrex, 2016; Stratone, Nelu: Rock sub seceră și ciocan (Rock under sickle and hammer), Bucharest, Hyperliteratura, 2017; Ionescu, Doru: Vocile jazzului românesc (Voices of Romanian jazz), Cluj-Napoca, Eikon, 2019. 
portunists, these "common" individuals simply refused to think and act in ways that would have harmonized entirely with the values that the communist regimes sought to impose, and thus understood before others the fundamental difference between a dictatorship and a democracy.

These silent agents of change turned into the social segment that actively contributed to Romania's transformation into a democracy, which is feeble today, but not put under question as in the neighbouring countries of Central Europe. At macro-societal level, these people were instrumental in triggering public debates on the communist past and pressed for the application of transitional justice and the opening of the Securitate files. These individuals marked the break with the communist past. At the mezzo-societal level, many of those who refused to adopt the value system of the communist regime were active in redefining professional fields or modelling new institutions by copying Western models and adapting them to the local context. These individuals definitely marked the post-1989 societal transformation in the direction of democratic consolidation. At the micro-societal level, all the non-conformists of yesterday, who conserved collections illustrating their efforts to think and act as if in a free country while actually under a ruthless dictatorship, also created invaluable sources. These contribute to a more nuanced grasp of the communist past and a better understanding of what the future should be, for their legacy is for generations to come, who could better understand what Europe is about by familiarizing themselves with stories from behind the Iron Curtain as those above. To sum up, the COURAGE open access e-database created by the Romanian team teaches the difference between dictatorship and democracy, while emphasising that beyond the European memory divide of the twentieth century there is a common cultural heritage which cherishes the fundamental European values. 